\title{
Acute Brain Ischemia, Infarction and Hemorrhage in Subjects Dying with or Without Autopsy-Proven Acute Pneumonia
}

\author{
Thomas G. Beach, Lucia I. Sue, \\ Anthony J. Intorcia, Michael J. Glass, Jessica E. Walker, Richard Arce, \\ Courtney M. Nelson and Geidy E. Serrano
}

Banner Sun Health Research Institute, Sun City, AZ

Correspondence: Thomas G. Beach,

Banner Sun Health Research Institute,

10515 West Santa Fe Drive, Sun City, AZ 85351

Telephone: 623-832-5643

Fax: 623-815-2960

thomas.beach@bannerhealth.com 
medRxiv preprint doi: https://doi.org/10.1101/2021.03.22.21254139; this version posted March 26, 2021. The copyright holder for this preprint (which was not certified by peer review) is the author/funder, who has granted medRxiv a license to display the preprint in perpetuity.

It is made available under a CC-BY-NC-ND 4.0 International license .

\section{Abstract}

Stroke is one of the most serious complications of Covid-19 disease but it is still unclear whether stroke is more common with Covid-19 pneumonia as compared to non-Covid-19 pneumonia. We investigated the concurrence rate of autopsy-confirmed acute brain ischemia, acute brain infarction and acute brain hemorrhage with autopsy-proven acute non-Covid pneumonia in consecutive autopsies in the Arizona Study of Aging and Neurodegenerative Disorders (AZSAND), a longitudinal clinicopathological study of normal aging and neurodegenerative diseases. Of 691 subjects with a mean age of 83.4 years, acute pneumonia was histopathologically diagnosed in $343(49.6 \%)$; the concurrence rates for histopathologically-confirmed acute ischemia, acute infarction or subacute infarction was $14 \%$ and did not differ between pneumonia and non-pneumonia groups while the rates of acute brain hemorrhage were $1.4 \%$ and $2.0 \%$ of those with or without acute pneumonia, respectively. In comparison, in reviews of Covid-19 publications, reported clinically-determined rates of acute brain infarction range from $0.5 \%$ to $20 \%$ while rates of acute brain hemorrhage range from $0.13 \%$ to $2 \%$. In reviews of Covid-19 autopsy studies, concurrence rates for both acute brain infarction and acute brain hemorrhage average about $10 \%$. Covid-19 pneumonia and non-Covid-19 pneumonia may have similar risks tor concurrent acute brain infarction and acute brain hemorrhage when pneumonia is severe enough to cause death. Additionally, acute brain ischemia, infarction or hemorrhage may not be more common in subjects dying of acute pneumonia than in subjects dying without acute pneumonia. 
medRxiv preprint doi: https://doi.org/10.1101/2021.03.22.21254139; this version posted March 26, 2021. The copyright holder for this preprint (which was not certified by peer review) is the author/funder, who has granted medRxiv a license to display the preprint in perpetuity.

It is made available under a CC-BY-NC-ND 4.0 International license .

\section{Introduction}

Studies of factors associated with acute pneumonia, a leading cause of death worldwide ${ }^{1}$, may have relevance for Covid-19 disease as both occur predominantly in the setting of epidemic viral respiratory infections ${ }^{2-4}$. Predisposing factors to both acute non-Covid-19 pneumonia and epidemic Covid-19 disease include wintertime occurrence, older age, and male sex, while obesity, pre-existing cardiopulmonary conditions, and diabetes are particularly associated with Covid-19 disease ${ }^{5-26}$. Also implicated as risk factors for both are age-related neurodegenerative diseases that cause parkinsonism and dementia ${ }^{27-44}$.

Stroke, both ischemic and hemorrhagic, is a catastrophic accompaniment of Covid-19 disease but the concurrence rate is difficult to ascertain due to a very wide range in existing clinical and autopsybased reports ${ }^{45-78}$. Also, it is uncertain whether either Covid-19 disease or non-Covid-19 pneumonia are more likely to be associated with stroke, or whether stroke is more or less common in patients hospitalized for other reasons. As diagnosis of both pneumonia and stroke are more accurately obtained at autopsy ${ }^{79-83}$ we investigated the concurrence of autopsy-proven pneumonia and acute stroke in the Arizona Study of Aging and Neurodegenerative Disorders (AZSAND), a longitudinal, clinicopathological study of normal aging and neurodegenerative diseases ${ }^{84}$. Volunteer participants are primarily elderly residents of metropolitan Phoenix, Arizona. The program includes annual clinical assessments of community volunteers by neuropsychologists and subspecialty neurologists, with eventual whole-body autopsies by medically-certified anatomical pathologists and a neuropathologist. The current study was undertaken to determine the frequency of ischemic and hemorrhagic intracranial lesions in autopsied participants with or without autopsy-diagnosed acute pneumonia, prior to the onset of the Covid-19 pandemic.

We have previously reported on clinical and pathological associations of acute pneumonia in this same set of subjects, finding that significant risk factors of acute pneumonia include wintertime occurrence, older age, male sex and neurodegenerative dementia or parksinsonism ${ }^{27}$. 
medRxiv preprint doi: https://doi.org/10.1101/2021.03.22.21254139; this version posted March 26, 2021. The copyright holder for this preprint (which was not certified by peer review) is the author/funder, who has granted medRxiv a license to display the preprint in perpetuity.

It is made available under a CC-BY-NC-ND 4.0 International license .

\section{Methods}

\section{Study subjects and clinical assessments}

The study population draws primarily on the retirement communities of greater Phoenix, Arizona. The residents are predominantly elderly, well-educated, Caucasian (greater than $90 \%$ ), middle- and upper-income individuals. Recruitment is directed at subjects with a clinical diagnosis of dementia, parkinsonism or cancer, or who are free of major neurological conditions. More than $70 \%$ of clinicallyfollowed subjects are living independently at the time of enrollment, without cognitive impairment or parkinsonism. Subjects with hazardous infectious diseases including HIV, hepatitis B or C, Creutzfeldt-Jakob disease and other infectious encephalopathies are excluded from enrollment.

The AZSAND, through its Brain and Body Donation Program (https://www.brainandbodydonationregistration.org/) performs constitutively-rapid autopsies (median postmortem interval 3.0 hours for all 2,000 + autopsies) on Program participants and shares tissue samples with biomedical researchers worldwide ${ }^{84}$. The Program is approved by an Institutional Review Board and written informed consent is obtained from all subjects or their legal representatives.

Standardized general medical, subspecialty neurological (behavioral/cognitive and movement disorders), and neuropsychological assessments are administered to most subjects annually. Clinical diagnostic classification is performed after each annual assessment, at a consensus conference attended by neurologists and neuropsychologists. A final clinicopathological diagnosis is assigned after death, after review of all standardized research clinical data, private medical records and neuropathological examination findings. The cause of death is recorded by the subjects' physician without knowledge of the eventual autopsy findings.

\section{Autopsy examinations}

Medically-certified pathologists perform all examinations. Lung sampling is directed at both grosslynormal and grossly-pathological regions. Acute pneumonia is diagnosed on the basis of microscopic findings, in hematoxylin and eosin-stained slides, of confluent intra-alveolar accumulations of neutrophil polymorphonuclear leukocytes, with or without a typical gross pathological appearance or microscopic 
medRxiv preprint doi: https://doi.org/10.1101/2021.03.22.21254139; this version posted March 26, 2021. The copyright holder for this preprint (which was not certified by peer review) is the author/funder, who has granted medRxiv a license to display the preprint in perpetuity.

It is made available under a CC-BY-NC-ND 4.0 International license .

evidence of bacterial colonies. The neuropathological diagnostic approach has been previously described and is supplemented by consideration of results of standardized annual neurological and neuropsychological assessments ${ }^{84}$. Published clinicopathological consensus criteria ${ }^{85-92}$ are used when they exist, incorporating clinical assessment results as well as pertinent private medical history. The presence of absence in the brain of acute or subacute infarcts, as well as acute hemorrhage, is recorded. Infarcts are subclassified as large (> $27 \mathrm{cc}$ ), small (2-27 cc), lacunar (grossly visible, 1-2 cc or less) or microscopic (not grossly visible, less than $1 \mathrm{cc}$ ). Acute ischemic changes without frank infarction are also recorded, including eosinophilic perikaryal neuronal cytoplasm, nuclear pyknosis, karyorrhexis or dissolution, loss of tissue eosinophilia and tissue microvacuolation. Hemorrhage is classified as large (> $27 \mathrm{cc}$ ) or small/microscopic.

\section{Associations tested and statistical methods}

Fisher's Exact Tests were used to test for associations of subject characteristics with pneumonia and different types of stroke or acute ischemic changes.

\section{Results}

Included in this study were 691 subjects with postmortem lung and brain examinations, done between March 2005 and December 2019 (Table 1). Of these, 405 were males (59\%) and 286 were females (41\%) with mean ages of 82.1 and 85.2 years, respectively. Acute pneumonia was diagnosed histopathologically in 343 subjects (49.6\%; 225 males and 118 females). This was almost entirely acute bronchopneumonia with a very small percentage of acute lobar pneumonia. In contrast, pneumonia or respiratory failure was listed as the cause of death (by the physician on the basis of clinical findings) in less than $1 \%$ of cases.

Histopathologically-confirmed acute ischemia, acute infarction or subacute infarction was present in $14 \%$ of brains from autopsied subjects, from both the pneumonia and non-pneumonia groups, while acute brain hemorrhage was present in $1.4 \%$ and $2.0 \%$ of those with or without acute pneumonia, respectively (Table 2). Of subtypes of infarction or ischemic changes and hemorrhage, only acute 
medRxiv preprint doi: https://doi.org/10.1101/2021.03.22.21254139; this version posted March 26, 2021. The copyright holder for this preprint (which was not certified by peer review) is the author/funder, who has granted medRxiv a license to display the preprint in perpetuity.

It is made available under a CC-BY-NC-ND 4.0 International license .

ischemic changes were significantly more common with pneumonia ( $2.6 \%$ vs $0.57 \% ; p=0.036 \%)$. Small or microscopic hemorrhages were present in 4 pneumonia cases but were not present in any non-pneumonia case. Stroke was listed as the clinical cause of death in less than $6 \%$ of cases.

Clinicopathological brain diagnoses other than stroke were predominantly a variety of neurodegenerative diseases, including 319 dementia subjects with Alzheimer's disease (AD), 127 subjects with idiopathic Parkinson's disease (PD), 72 subjects with dementia with Lewy bodies (DLB), 78 with vascular dementia $(\mathrm{VaD})$ and 49 with diagnostic histopathology of progressive supranuclear palsy (PSP). These diagnoses are not mutually exclusive as many of the subjects had more than one neuropathological diagnosis. Additionally, 185 subjects had neither dementia or parkinsonism and had less-than-diagnostic neurodegenerative changes. Of the 319 AD cases, 34 also had clinicopathologically-diagnosed PD, 62 had DLB, 60 had $\mathrm{VaD}$ and 16 had progressive supranuclear palsy. Other neurodegenerative conditions diagnosed but not statistically tested for associations with pneumonia or stroke due to low subject numbers included frontotemporal lobar degeneration with TDP43 proteinopathy $(n=14)$, corticobasal degeneration $(n=7)$ and Pick's disease $(n=4$.)

A neuropathological diagnosis of vascular dementia and a clinical diagnosis of atrial fibrillation were both significantly more likely to have had an autopsy diagnosis of acute brain ischemia or infarction (Table 3). Female subjects, subjects over age 85, subjects with severe circle of Willis atherosclerosis and congestive heart failure were more likely, and subjects with a neuropathological diagnosis of $A D$ were less likely to have had acute brain ischemia or infarction; these associations did not reach significance levels.

\section{Discussion}

Although stroke and a wide range of neurological signs and symptoms have been reported as relatively common accompaniments of Covid-19 disease, most reports have lacked an appropriate control group. As direct CNS infection with SARS-CoV-2 may occur only in a minority of those with 
medRxiv preprint doi: https://doi.org/10.1101/2021.03.22.21254139; this version posted March 26, 2021. The copyright holder for this preprint (which was not certified by peer review) is the author/funder, who has granted medRxiv a license to display the preprint in perpetuity.

It is made available under a CC-BY-NC-ND 4.0 International license .

Covid-19 disease ${ }^{93}$, much of the reported neurological phenomena may occur not through direct SARS-CoV-2 infection of neural tissue but indirectly, via systemic complications of critical illness such as sepsis, coagulopathy, hyperimmune reactions or multi-organ failure. Better estimates of the specificity of any non-pulmonary Covid-19 accompaniments will only be possible by comparison with their concurrence rates in other types of critical illness.

Stroke is perhaps the most serious non-pulmonary complication of Covid-19 but its concurrent prevalence is difficult to ascertain due to a very wide range in existing clinical and autopsy-based reports ${ }^{45-78}$. Non-Covid-19 pneumonia may be a useful control condition with which to approach this issue, as like Covid-19 disease, it is a life-threatening lung infection that frequently has systemic effects including sepsis, coagulopathy and multi-organ failure ${ }^{94}$. As the diagnosis of both pneumonia and stroke are more accurately obtained at autopsy ${ }^{79-83}$ we investigated the concurrence of autopsy-proven pneumonia and acute stroke in the Arizona Study of Aging and Neurodegenerative Disorders (AZSAND), a longitudinal, clinicopathological study of normal aging and neurodegenerative diseases ${ }^{84}$. In this study of a suburban-dwelling, predominantly Caucasian middle-class population of advanced age, acute ischemic changes and acute infarctions were common autopsy findings, occurring in $14 \%$ of subjects regardless of the presence or absence of concurrent acute pneumonia. This finding supports previous studies that indicate that acute ischemia and acute infarction are very common in subjects with critical illnesses resulting in death, regardless of whether pneumonia is also present, and that these strokes are often clinically unrecognized ${ }^{95}$. The rates of clinical cause-of-death attribution, for both pneumonia and stroke in our study, are even lower than for reported clinicopathological studies; this is likely because the majority of subjects in our program die on hospice care and thus do not receive elaborate perimortem medical investigation or treatment.

Acute brain hemorrhage was an infrequent finding, with insufficient case numbers for statistical evaluation. We found significant associations of acute brain ischemia or infarction with a history of atrial fibrillation, as well as a diagnosis of vascular dementia, both of which are well known to be associated with higher risks of stroke ${ }^{96-100}$. 
medRxiv preprint doi: https://doi.org/10.1101/2021.03.22.21254139; this version posted March 26, 2021. The copyright holder for this preprint (which was not certified by peer review) is the author/funder, who has granted medRxiv a license to display the preprint in perpetuity.

It is made available under a CC-BY-NC-ND 4.0 International license .

In comparison, in reviews of Covid-19 publications, reported clinically and autopsy-determined rates of acute brain infarction range from $0.5 \%$ to $20 \%$ while rates of acute brain hemorrhage range from $0.13 \%$ to $9.5 \%{ }^{45-78}$. A small number of clinical studies have also compared rates of stroke in hospitalized patients with Covid-19 versus influenza, with two studies finding increased rates with Covid- $19^{74,75}$ (1.6\% vs $0.2 \%$ and $0.9 \%$ vs $\left.0.3 \%\right)$ and one finding equivalent rates ${ }^{45} \mathrm{~T}(1.2 \%$ for both). As these rates are all much smaller than what we have found here and as clinical detection of both stroke and pneumonia is poorly sensitive compared to autopsy ${ }^{79-83,95}$, the overall likelihood is that Covid-19 pneumonia and non-Covid-19 pneumonia may have similar risks tor concurrent acute brain infarction and acute brain hemorrhage when pneumonia is severe enough to cause death, and stroke overall may not be differentially prevalent in subjects dying with either type of pneumonia or non-Covid19 pneumonia as compared to subjects dying from other causes.

A limitation of our study is the lack of identification of the responsible pathogens. This is a common limitation to pneumonia studies ${ }^{101}$. When pathogens are identified, they are viral more often than bacterial, with the top three in US hospitalized patients being human rhinovirus, influenza $A$ and $B$, and Streptococcus pneumoniae ${ }^{102}$. Although we did not attempt to determine, from clinical records or postmortem culture, the presence of associated pathogens, the confluent intra-alveolar accumulation of neutrophils is generally regarded as indicative of a bacterial cause ${ }^{103}$ and therefore this study is likely to have been biased towards the inclusion of bacterial pneumonia and against the inclusion of purely viral pneumonia, although mixed bacterial and viral causes were very likely to have been common ${ }^{101}$ 102103. 
medRxiv preprint doi: https://doi.org/10.1101/2021.03.22.21254139; this version posted March 26, 2021. The copyright holder for this preprint (which was not certified by peer review) is the author/funder, who has granted medRxiv a license to display the preprint in perpetuity. It is made available under a CC-BY-NC-ND 4.0 International license.

\section{Acknowledgements}

This project was supported by a Covid-19-focused supplement to a National Institute on Aging grant (3P30AG019610-20S1), submitted in response to a Notice of Special Interest (NOSI) issued by the National Institute on Aging (NOT-AG-20-022), "to highlight the urgent need for research on Coronavirus Disease 2019...". The Brain and Body Donation Program has been supported by the National Institute of Neurological Disorders and Stroke (U24 NS072026 National Brain and Tissue Resource for Parkinson's Disease and Related Disorders), the National Institute on Aging (P30 AG19610 Arizona Alzheimer's Disease Core Center), the Arizona Department of Health Services (contract 211002, Arizona Alzheimer's Research Center), the Arizona Biomedical Research Commission (contracts 4001, 0011, 05-901 and 1001 to the Arizona Parkinson's Disease Consortium) and the Michael J. Fox Foundation for Parkinson's Research. 
medRxiv preprint doi: https://doi.org/10.1101/2021.03.22.21254139; this version posted March 26, 2021. The copyright holder for this preprint (which was not certified by peer review) is the author/funder, who has granted medRxiv a license to display the preprint in perpetuity.

It is made available under a CC-BY-NC-ND 4.0 International license .

Table 1. Neuropathological and clinical classification of study subjects. Norm = non-demented without parkinsonism; $A D$ = Alzheimer's disease; $P D=$ Parkinson's disease; $D L B$ = dementia with Lewy bodies; $\mathrm{VaD}=$ vascular dementia; PSP = progressive supranuclear palsy.

\begin{tabular}{|l|c|c|c|c|c|c|c|}
\hline & ALL & Norm & AD & PD & DLB & VaD & PSP \\
\hline Number & 691 & 185 & 319 & 127 & 72 & 78 & 49 \\
\hline Age (SD) & $83.4(9.6)$ & $85(3.5)$ & $84.3(2.8)$ & $80(2.1)$ & $83.6(9.2)$ & $89.3(10.6)$ & $86.4(6.8)$ \\
\hline M/F & $405 / 286$ & $112 / 73$ & $182 / 137$ & $89 / 38$ & $51 / 21$ & $39 / 39$ & $30 / 19$ \\
\hline
\end{tabular}

Table 2. Concurrence rates of histopathological evidence of acute or subacute brain infarction or ischemia or acute hemorrhage, or of acute stroke as a listed clinical cause of death, in subjects with and without a histopathological diagnosis of acute pneumonia. Fisher Exact tests were used to compare proportions.

\begin{tabular}{|l|c|c|c|}
\hline \multicolumn{1}{|c|}{ Variable } & Pneumonia & No Pneumonia & P Statistic \\
\hline Acute Brain Infarction/Ischemia, Any & $49 / 343(14 \%)$ & $48 / 348(14 \%)$ & $\mathrm{ns}$ \\
\hline Large Acute Brain Infarction & $19 / 343(5.5 \%)$ & $15 / 348(4.3 \%)$ & $\mathrm{ns}$ \\
\hline Small Acute Brain Infarction & $9 / 343(2.6 \%)$ & $9 / 348(2.6 \%)$ & $\mathrm{ns}$ \\
\hline Lacunar Acute Brain Infarction & $11 / 343(3.2 \%)$ & $9 / 348(2.6 \%)$ & $\mathrm{ns}$ \\
\hline Microscopic Acute Brain Infarction & $16 / 343(4.7 \%)$ & $19 / 348(5.5 \%)$ & $\mathrm{ns}$ \\
\hline Microscopic Acute Ischemic Changes & $9 / 343(2.6 \%)$ & $2 / 348(0.57 \%)$ & 0.036 \\
\hline Any Acute Brain Hemorrhage & $5 / 343(1.4 \%)$ & $7 / 348(2.0 \%)$ & $\mathrm{ns}$ \\
\hline Large Acute Brain Hemorrhage & $3 / 343(0.87 \%)$ & $7 / 348(2.0 \%)$ & $\mathrm{ns}$ \\
\hline Small/Micro Acute Brain Hemorrhage & $4 / 343(1.2 \%)$ & $0 / 348(0 \%)$ & $\mathrm{ns}$ \\
\hline Old Brain Infarction, Any & $131 / 343(38 \%)$ & $143 / 348(41 \%)$ & $\mathrm{ns}$ \\
\hline Stroke as Clinical Cause of Death & $11 / 343(3.2 \%)$ & $20 / 348(5.7 \%)$ & $\mathrm{ns}$ \\
\hline Pneumonia as Clinical Cause of Death & $35 / 343(1 \%)$ & $31 / 348(0.9 \%)$ & $\mathrm{ns}$ \\
\hline
\end{tabular}


medRxiv preprint doi: https://doi.org/10.1101/2021.03.22.21254139; this version posted March 26, 2021. The copyright holder for this preprint (which was not certified by peer review) is the author/funder, who has granted medRxiv a license to display the preprint in perpetuity.

It is made available under a CC-BY-NC-ND 4.0 International license .

Table 3. Comparison of subject characteristics of those with and without histopathologically-proven acute or subacute brain ischemia or infarction. Fisher Exact tests were used to compare proportions. Obesity is defined as BMI 30 or greater. Cardiomegaly is defined as heart weight $>360 \mathrm{~g}$ for males and $>280 \mathrm{~g}$ for females. Older age is defined as greater than the median age of 84 . Cerebral atherosclerosis is defined as an autopsy-based circle of Willis score of severe. Any ApoE4 = apolipoprotein $\mathrm{E}$ genotype heterozygous or homozygous for the $\varepsilon 4$ allele.

\begin{tabular}{|l|c|c|c|}
\hline \multicolumn{1}{|c|}{ Variable } & $\begin{array}{l}\text { Acute } \\
\text { Ischemia/Infarction }\end{array}$ & $\begin{array}{c}\text { No Acute } \\
\text { Ischemia/Infarction }\end{array}$ & P Statistic \\
\hline Stroke as Clinical Cause of Death & $16 / 343(4.7 \%)$ & $15 / 348(4.3 \%)$ & $\mathrm{ns}$ \\
\hline Male & $53 / 97(55 \%)$ & $325 / 594(55 \%)$ & $\mathrm{ns}$ \\
\hline Female & $44 / 97(45 \%)$ & $242 / 594(41 \%)$ & $\mathrm{ns}$ \\
\hline Older Age & $56 / 97(58 \%)$ & $280 / 594(47 \%)$ & $\mathrm{ns}$ \\
\hline AD & $35 / 97(36 \%)$ & $284 / 594(48 \%)$ & $\mathrm{ns}$ \\
\hline PD & $17 / 97(17.5 \%)$ & $110 / 594(18.5 \%)$ & $\mathrm{ns}$ \\
\hline DLB & $9 / 97(9 \%)$ & $63 / 594(6 \%)$ & $\mathrm{ns}$ \\
\hline VaD & $21 / 97(22 \%)$ & $56 / 594(9 \%)$ & 0.0013 \\
\hline PSP & $5 / 97(5 \%)$ & $44 / 594(7 \%)$ & $\mathrm{ns}$ \\
\hline Any ApoE4 ${ }^{1}$ & $27 / 97(28 \%)$ & $187 / 586(32 \%)$ & $\mathrm{ns}$ \\
\hline Non-Summer Death & $77 / 97(79 \%)$ & $455 / 594(77 \%)$ & $\mathrm{ns}$ \\
\hline COPD & $25 / 97(26 \%)$ & $160 / 594(27 \%)$ & $\mathrm{ns}$ \\
\hline Old brain infarction, Any & $43 / 97(44 \%)$ & $231 / 594(39 \%)$ & $\mathrm{ns}$ \\
\hline Obesity (BMI 30 or greater) ${ }^{2}$ & $26 / 97(27 \%)$ & $153 / 571(24 \%)$ & $\mathrm{ns}$ \\
\hline Cardiomegaly & $72 / 97(74 \%)$ & $443 / 589(75 \%)$ & $\mathrm{ns}$ \\
\hline Circle of Willis atherosclerosis & $34 / 97(35 \%)$ & $168 / 594(28 \%)$ & $\mathrm{ns}$ \\
\hline Atrial fibrillation & $37 / 97(38 \%)$ & $159 / 594(27 \%)$ & 0.03 \\
\hline Congestive Heart Failure & $31 / 97(32 \%)$ & $137 / 594(23 \%)$ & $\mathrm{ns}$ \\
\hline Hypertension & $73 / 97(75 \%)$ & $421 / 594(71 \%)$ & $\mathrm{ns}$ \\
\hline Diabetes & $27 / 97(28 \%)$ & $137 / 594(23 \%)$ & $\mathrm{ns}$ \\
\hline Cigarette Smoker & $37 / 97(38 \%)$ & $277 / 594(47 \%)$ & $\mathrm{ns}$ \\
\hline & & & \\
\hline
\end{tabular}

1. Eight subjects without acute ischemia/infarction had no apolipoprotein E genotyping available.

2. Twenty-three subjects without acute ischemia/infarction had no BMI values available.

3. Five subjects without acute ischemia/infarction had no heart weight available. 
medRxiv preprint doi: https://doi.org/10.1101/2021.03.22.21254139; this version posted March 26, 2021. The copyright holder for this preprint (which was not certified by peer review) is the author/funder, who has granted medRxiv a license to display the preprint in perpetuity. It is made available under a CC-BY-NC-ND 4.0 International license .

\section{References}

1. Lanks, CW, Musani, Al, and Hsia, DW. Community-acquired Pneumonia and Hospital-acquired Pneumonia. Med Clin North Am. 2019; 103:487-501.

2. Morens, DM, Taubenberger, JK, and Fauci, AS. Predominant role of bacterial pneumonia as a cause of death in pandemic influenza: implications for pandemic influenza preparedness. J Infect Dis. 2008; 198:962-970.

3. Maclntyre, CR, Chughtai, AA, Barnes, M, et al. The role of pneumonia and secondary bacterial infection in fatal and serious outcomes of pandemic influenza a(H1N1)pdm09. BMC Infect Dis. 2018; 18:637.

4. Grosse, C, Grosse, A, Salzer, HJF, et al. Analysis of cardiopulmonary findings in COVID-19 fatalities: High incidence of pulmonary artery thrombi and acute suppurative bronchopneumonia. Cardiovasc Pathol. 2020; 49:107263.

5. Andersson, MI, Arancibia-Carcamo, CV, Auckland, K, et al. SARS-CoV-2 RNA detected in blood products from patients with COVID-19 is not associated with infectious virus. Wellcome Open Res. 2020; 5:181.

6. Mizgerd, JP. Inflammation and Pneumonia: Why Are Some More Susceptible than Others? Clin Chest Med. 2018; 39:669-676.

7. Lipsitch, M and Viboud, C. Influenza seasonality: lifting the fog. Proc Natl Acad Sci U S A. 2009; 106:3645-3646.

8. Martinez, ME. The calendar of epidemics: Seasonal cycles of infectious diseases. PLoS Pathog. 2018; 14:e1007327. 
medRxiv preprint doi: https://doi.org/10.1101/2021.03.22.21254139; this version posted March 26, 2021. The copyright holder for this preprint (which was not certified by peer review) is the author/funder, who has granted medRxiv a license to display the preprint in perpetuity. It is made available under a CC-BY-NC-ND 4.0 International license.

9. Frasca, D and McElhaney, J. Influence of Obesity on Pneumococcus Infection Risk in the Elderly. Front Endocrinol (Lausanne ). 2019; 10:71.

10. Hespanhol, V and Barbara, C. Pneumonia mortality, comorbidities matter? Pulmonology. 2020; 26:123-129.

11. Kalil, AC and Thomas, PG. Influenza virus-related critical illness: pathophysiology and epidemiology. Crit Care. 2019; 23:258.

12. Peters, SAE, MacMahon, S, and Woodward, M. Obesity as a risk factor for COVID-19 mortality in women and men in the UK biobank: Comparisons with influenza/pneumonia and coronary heart disease. Diabetes Obes Metab. 2020.

13. Suleyman, G, Fadel, RA, Malette, KM, et al. Clinical Characteristics and Morbidity Associated With Coronavirus Disease 2019 in a Series of Patients in Metropolitan Detroit. JAMA Netw Open. 2020; 3:e2012270.

14. Richardson, S, Hirsch, JS, Narasimhan, M, et al. Presenting Characteristics, Comorbidities, and Outcomes Among 5700 Patients Hospitalized With COVID-19 in the New York City Area. JAMA. 2020; 323:2052-2059.

15. Engin, AB, Engin, ED, and Engin, A. Two important controversial risk factors in SARS-CoV-2 infection: Obesity and smoking. Environ Toxicol Pharmacol. 2020; 78:103411.

16. Palaiodimos, L, Kokkinidis, DG, Li, W, et al. Severe obesity, increasing age and male sex are independently associated with worse in-hospital outcomes, and higher in-hospital mortality, in a cohort of patients with COVID-19 in the Bronx, New York. Metabolism. $2020 ; 108: 154262$. 
medRxiv preprint doi: https://doi.org/10.1101/2021.03.22.21254139; this version posted March 26, 2021. The copyright holder for this preprint (which was not certified by peer review) is the author/funder, who has granted medRxiv a license to display the preprint in perpetuity. It is made available under a CC-BY-NC-ND 4.0 International license .

17. Kaplan, V, Angus, DC, Griffin, MF, et al. Hospitalized community-acquired pneumonia in the elderly: age- and sex-related patterns of care and outcome in the United States. Am J Respir Crit Care Med. 2002; 165:766-772.

18. Pasquale, CB, Vietri, J, Choate, R, et al. Patient-Reported Consequences of CommunityAcquired Pneumonia in Patients with Chronic Obstructive Pulmonary Disease. Chronic Obstr Pulm Dis. 2019; 6:132-144.

19. Patil, A, Tripathy, JP, Deshmukh, V, et al. SeXX and COVID-19: tussle between the two. Monaldi Arch Chest Dis. 2020; 90.

20. Aggarwal, G, Lippi, G, Lavie, CJ, et al. Diabetes mellitus association with coronavirus disease 2019 (COVID-19) severity and mortality: A pooled analysis. J Diabetes. 2020; 12:851855.

21. Aggarwal, G, Lippi, G, and Michael, HB. Cerebrovascular disease is associated with an increased disease severity in patients with Coronavirus Disease 2019 (COVID-19): A pooled analysis of published literature. Int J Stroke. 2020; 15:385-389.

22. Aggarwal, G, Cheruiyot, I, Aggarwal, S, et al. Association of Cardiovascular Disease With Coronavirus Disease 2019 (COVID-19) Severity: A Meta-Analysis. Curr Probl Cardiol. $2020 ; 45: 100617$.

23. Edler, C, Schroder, AS, Aepfelbacher, M, et al. Dying with SARS-CoV-2 infection-an autopsy study of the first consecutive 80 cases in Hamburg, Germany. Int J Legal Med. 2020; 134:1275-1284.

24. Gebhard, C, Regitz-Zagrosek, V, Neuhauser, HK, et al. Impact of sex and gender on COVID-19 outcomes in Europe. Biol Sex Differ. 2020; 11:29. 
medRxiv preprint doi: https://doi.org/10.1101/2021.03.22.21254139; this version posted March 26, 2021. The copyright holder for this preprint (which was not certified by peer review) is the author/funder, who has granted medRxiv a license to display the preprint in perpetuity. It is made available under a CC-BY-NC-ND 4.0 International license .

25. Ssentongo, P, Ssentongo, AE, Heilbrunn, ES, et al. Association of cardiovascular disease and 10 other pre-existing comorbidities with COVID-19 mortality: A systematic review and meta-analysis. PLoS One. 2020; 15:e0238215.

26. Hussain, A, Mahawar, K, Xia, Z, et al. Obesity and mortality of COVID-19. Meta-analysis. Obes Res Clin Pract. 2020; 14:295-300.

27. Beach, TG, Russell, A, Sue, LI, et al. Increased Risk of Autopsy-Proven Pneumonia with Sex, Season and Neurodegenerative Disease. medRxiv. 2021.

28. Attems, J, Konig, C, Huber, M, et al. Cause of death in demented and non-demented elderly inpatients; an autopsy study of 308 cases. J Alzheimers Dis. 2005; 8:57-62.

29. Wang, X, You, G, Chen, H, et al. Clinical course and cause of death in elderly patients with idiopathic Parkinson's disease. Chin Med J (Engl ). 2002; 115:1409-1411.

30. Degerskar, ANW and Englund, EM. Cause of death in autopsy-confirmed dementia disorders. Eur J Neurol. 2020.

31. Litvan, I, Mangone, CA, McKee, A, et al. Natural history of progressive supranuclear palsy (Steele-Richardson-Olszewski syndrome) and clinical predictors of survival: a clinicopathological study. J Neurol Neurosurg Psychiatry. 1996; 60:615-620.

32. Shea, YF, Shum, ACK, Lee, SC, et al. Natural clinical course of progressive supranuclear palsy in Chinese patients in Hong Kong. Hong Kong Med J. 2019; 25:444-452.

33. Covino, M, De, MG, Santoro, M, et al. Clinical characteristics and prognostic factors in COVID19 patients aged >/=80 years. Geriatr Gerontol Int. 2020; 20:704-708. 
medRxiv preprint doi: https://doi.org/10.1101/2021.03.22.21254139; this version posted March 26, 2021. The copyright holder for this preprint (which was not certified by peer review) is the author/funder, who has granted medRxiv a license to display the preprint in perpetuity. It is made available under a CC-BY-NC-ND 4.0 International license .

34. Atkins, JL, Masoli, JAH, Delgado, J, et al. Preexisting Comorbidities Predicting COVID-19 and Mortality in the UK Biobank Community Cohort. J Gerontol A Biol Sci Med Sci. 2020; 75:2224-2230.

35. Beatty, JA, Majumdar, SR, Tyrrell, GJ, et al. Prognostic factors associated with mortality and major in-hospital complications in patients with bacteremic pneumococcal pneumonia: Population-based study. Medicine (Baltimore ). 2016; 95:e5179.

36. Noguchi, S, Yatera, K, Kato, T, et al. Impact of the number of aspiration risk factors on mortality and recurrence in community-onset pneumonia. Clin Interv Aging. 2017; 12:2087-2094.

37. Rao, A, Suliman, A, Vuik, S, et al. Outcomes of dementia: Systematic review and meta-analysis of hospital administrative database studies. Arch Gerontol Geriatr. 2016; 66:198-204.

38. Boivin, Z, Perez, MF, Atuegwu, NC, et al. Association of atypical antipsychotics and mortality for patients hospitalised with pneumonia. ERJ Open Res. 2019; 5.

39. Fall, PA, Saleh, A, Fredrickson, M, et al. Survival time, mortality, and cause of death in elderly patients with Parkinson's disease: a 9-year follow-up. Mov Disord. 2003; 18:1312-1316.

40. Magaki, S, Yong, WH, Khanlou, N, et al. Comorbidity in dementia: update of an ongoing autopsy study. J Am Geriatr Soc. 2014; 62:1722-1728.

41. Foley, NC, Affoo, RH, and Martin, RE. A systematic review and meta-analysis examining pneumonia-associated mortality in dementia. Dement Geriatr Cogn Disord. 2015; 39:5267.

42. Manabe, T, Mizukami, K, Akatsu, H, et al. Prognostic Factors Related to Dementia with Lewy Bodies Complicated with Pneumonia: An Autopsy Study. Intern Med. 2016; 55:27712776. 
medRxiv preprint doi: https://doi.org/10.1101/2021.03.22.21254139; this version posted March 26, 2021. The copyright holder for this preprint (which was not certified by peer review) is the author/funder, who has granted medRxiv a license to display the preprint in perpetuity. It is made available under a CC-BY-NC-ND 4.0 International license .

43. Chang, YP, Yang, CJ, Hu, KF, et al. Risk factors for pneumonia among patients with Parkinson's disease: a Taiwan nationwide population-based study. Neuropsychiatr Dis Treat. 2016; 12:1037-1046.

44. Nath, U, Thomson, R, Wood, R, et al. Population based mortality and quality of death certification in progressive supranuclear palsy (Steele-Richardson-Olszewski syndrome). J Neurol Neurosurg Psychiatry. 2005; 76:498-502.

45. Piroth, L, Cottenet, J, Mariet, AS, et al. Comparison of the characteristics, morbidity, and mortality of COVID-19 and seasonal influenza: a nationwide, population-based retrospective cohort study. Lancet Respir Med. 2020.

46. Nannoni, S, de, GR, Bell, S, et al. Stroke in COVID-19: A systematic review and meta-analysis. Int J Stroke. 2021; 16:137-149.

47. Anand, PZLBNHDHGDMC-AAM. Neurologic Findings Among Inpatients with COVID-19 at a Safety-Net U.S. Hospital. Neurology Clin Practive. 2020; In press.

48. Deigendesch, N, Sironi, L, Kutza, M, et al. Correlates of critical illness-related encephalopathy predominate postmortem COVID-19 neuropathology. Acta Neuropathol. 2020; 140:583586.

49. Al-Dalahmah, O, Thakur, KT, Nordvig, AS, et al. Neuronophagia and microglial nodules in a SARS-CoV-2 patient with cerebellar hemorrhage. Acta Neuropathol Commun. 2020; 8:147.

50. Bihlmaier, K, Coras, R, Willam, C, et al. Disseminated Multifocal Intracerebral Bleeding Events in Three Coronavirus Disease 2019 Patients on Extracorporeal Membrane Oxygenation As Rescue Therapy. Crit Care Explor. 2020; 2:e0218. 
medRxiv preprint doi: https://doi.org/10.1101/2021.03.22.21254139; this version posted March 26, 2021. The copyright holder for this preprint (which was not certified by peer review) is the author/funder, who has granted medRxiv a license to display the preprint in perpetuity. It is made available under a CC-BY-NC-ND 4.0 International license .

51. Bradley, BT, Maioli, H, Johnston, R, et al. Histopathology and ultrastructural findings of fatal COVID-19 infections in Washington State: a case series. Lancet. 2020; 396:320-332.

52. Bryce, C, Grimes, Z, Pujadas, E, et al. Pathophysiology of SARS-CoV-2: targeting of endothelial cells renders a complex disease with thrombotic microangiopathy and aberrant immune response. The Mount Sinai COVID-19 autopsy experience. medRxiv. $2020 ; 2020$.

53. Conklin, J, Frosch, MP, Mukerji, S, et al. Cerebral Microvascular Injury in Severe COVID-19. medRxiv. 2020.

54. Coolen, T, Lolli, V, Sadeghi, N, et al. Early postmortem brain MRI findings in COVID-19 nonsurvivors. Neurology. 2020; 95:e2016-e2027.

55. Deinhardt-Emmer, S, Wittschieber, D, Sanft, J, et al. Early postmortem mapping of SARS-CoV2 RNA in patients with COVID-19 and correlation to tissue damage. bioRxiv. 2020;2020.

56. Jaunmuktane, Z, Mahadeva, U, Green, A, et al. Microvascular injury and hypoxic damage: emerging neuropathological signatures in COVID-19. Acta Neuropathol. 2020; 140:397400.

57. Jensen, MP, Le, QJ, Officer-Jones, L, et al. Neuropathological findings in two patients with fatal COVID-19. Neuropathol Appl Neurobiol. 2020.

58. Kantonen, J, Mahzabin, S, Mayranpaa, MI, et al. Neuropathologic features of four autopsied COVID-19 patients. Brain Pathol. 2020; 30:1012-1016.

59. Kirschenbaum, D, Imbach, LL, Rushing, EJ, et al. Intracerebral endotheliitis and microbleeds are neuropathological features of COVID-19. Neuropathol Appl Neurobiol. 2020. 
medRxiv preprint doi: https://doi.org/10.1101/2021.03.22.21254139; this version posted March 26, 2021. The copyright holder for this preprint (which was not certified by peer review) is the author/funder, who has granted medRxiv a license to display the preprint in perpetuity. It is made available under a CC-BY-NC-ND 4.0 International license .

60. Matschke, J, Lutgehetmann, M, Hagel, C, et al. Neuropathology of patients with COVID-19 in Germany: a post-mortem case series. Lancet Neurol. 2020; 19:919-929.

61. Meinhardt, J, Radke, J, Dittmayer, C, et al. Olfactory transmucosal SARS-CoV-2 invasion as a port of central nervous system entry in individuals with COVID-19. Nat Neurosci. 2020.

62. Menter, T, Haslbauer, JD, Nienhold, R, et al. Postmortem examination of COVID-19 patients reveals diffuse alveolar damage with severe capillary congestion and variegated findings in lungs and other organs suggesting vascular dysfunction. Histopathology. 2020; 77:198-209.

63. Radmanesh, A, Raz, E, Zan, E, et al. Brain Imaging Use and Findings in COVID-19: A Single Academic Center Experience in the Epicenter of Disease in the United States. AJNR Am J Neuroradiol. 2020; 41:1179-1183.

64. Reichard, RR, Kashani, KB, Boire, NA, et al. Neuropathology of COVID-19: a spectrum of vascular and acute disseminated encephalomyelitis (ADEM)-like pathology. Acta Neuropathol. 2020; 140:1-6.

65. Remmelink, M, De, MR, D'Haene, N, et al. Unspecific post-mortem findings despite multiorgan viral spread in COVID-19 patients. Crit Care. 2020; 24:495.

66. Solomon, IH, Normandin, E, Bhattacharyya, S, et al. Neuropathological Features of Covid-19. N Engl J Med. 2020; 383:989-992.

67. Song, E, Zhang, C, Israelow, B, et al. Neuroinvasion of SARS-CoV-2 in human and mouse brain. bioRxiv. 2020.

68. von Weyhern, $\mathrm{CH}$, Kaufmann, I, Neff, F, et al. Early evidence of pronounced brain involvement in fatal COVID-19 outcomes. Lancet. 2020; 395:e109. 
medRxiv preprint doi: https://doi.org/10.1101/2021.03.22.21254139; this version posted March 26, 2021. The copyright holder for this preprint (which was not certified by peer review) is the author/funder, who has granted medRxiv a license to display the preprint in perpetuity. It is made available under a CC-BY-NC-ND 4.0 International license .

69. Lee, MH, Perl, DP, Nair, G, et al. Microvascular Injury in the Brains of Patients with Covid-19. N Engl J Med. 2020.

70. Beyrouti, R, Best, JG, Chandratheva, A, et al. Characteristics of intracerebral haemorrhage associated with COVID-19: a systematic review and pooled analysis of individual patient and aggregate data. J Neurol. 2021.

71. Beyrouti, R, Adams, ME, Benjamin, L, et al. Characteristics of ischaemic stroke associated with COVID-19. J Neurol Neurosurg Psychiatry. 2020; 91:889-891.

72. Diener, HC, Berlit, P, and Masjuan, J. COVID-19: patients with stroke or risk of stroke. Eur Heart J Suppl. 2020; 22:25-28.

73. Ghannam, M, Alshaer, Q, Al-Chalabi, M, et al. Neurological involvement of coronavirus disease 2019: a systematic review. J Neurol. 2020; 267:3135-3153.

74. Merkler, AE, Parikh, NS, Mir, S, et al. Risk of Ischemic Stroke in Patients With Coronavirus Disease 2019 (COVID-19) vs Patients With Influenza. JAMA Neurol. 2020.

75. Nersesjan, V, Amiri, M, Christensen, HK, et al. Thirty-Day Mortality and Morbidity in COVID-19 Positive vs. COVID-19 Negative Individuals and vs. Individuals Tested for Influenza A/B: A Population-Based Study. Front Med (Lausanne ). 2020; 7:598272.

76. Ramos-Araque, ME, Siegler, JE, Ribo, M, et al. Stroke etiologies in patients with COVID-19: the SVIN COVID-19 multinational registry. BMC Neurol. 2021; 21:43.

77. Rothstein, A, Oldridge, O, Schwennesen, $\mathrm{H}$, et al. Acute Cerebrovascular Events in Hospitalized COVID-19 Patients. Stroke. 2020; 51:e219-e222. 
medRxiv preprint doi: https://doi.org/10.1101/2021.03.22.21254139; this version posted March 26, 2021. The copyright holder for this preprint (which was not certified by peer review) is the author/funder, who has granted medRxiv a license to display the preprint in perpetuity. It is made available under a CC-BY-NC-ND 4.0 International license .

78. Siow, I, Lee, KS, Zhang, JJY, et al. Stroke as a Neurological Complication of COVID-19: A Systematic Review and Meta-Analysis of Incidence, Outcomes and Predictors. J Stroke Cerebrovasc Dis. 2021; 30:105549.

79. Attems, J, Arbes, S, Bohm, G, et al. The clinical diagnostic accuracy rate regarding the immediate cause of death in a hospitalized geriatric population; an autopsy study of 1594 patients. Wien Med Wochenschr. 2004; 154:159-162.

80. Ravakhah, K. Death certificates are not reliable: revivification of the autopsy. South Med J. 2006; 99:728-733.

81. Abdel-Karim, IA, Sammel, RB, and Prange, MA. Causes of death at autopsy in an inpatient hospice program. J Palliat Med. 2007; 10:894-898.

82. Mieno, MN, Tanaka, N, Arai, T, et al. Accuracy of Death Certificates and Assessment of Factors for Misclassification of Underlying Cause of Death. J Epidemiol. 2016; 26:191198.

83. Manabe, T, Fujikura, Y, Mizukami, K, et al. Pneumonia-associated death in patients with dementia: A systematic review and meta-analysis. PLoS One. 2019; 14:e0213825.

84. Beach, TG, Adler, CH, Sue, LI, et al. Arizona Study of Aging and Neurodegenerative Disorders and Brain and Body Donation Program. Neuropathology. 2015; 35:354-389.

85. Roman, GC, Tatemichi, TK, Erkinjuntti, T, et al. Vascular dementia: diagnostic criteria for research studies. Report of the NINDS-AIREN International Workshop. Neurology. 1993; 43:250-260.

86. Mackenzie, IR, Neumann, M, Baborie, A, et al. A harmonized classification system for FTLDTDP pathology. Acta Neuropathol. 2011; 122:111-113. 
medRxiv preprint doi: https://doi.org/10.1101/2021.03.22.21254139; this version posted March 26, 2021. The copyright holder for this preprint (which was not certified by peer review) is the author/funder, who has granted medRxiv a license to display the preprint in perpetuity. It is made available under a CC-BY-NC-ND 4.0 International license .

87. Gelb, DJ, Oliver, E, and Gilman, S. Diagnostic criteria for Parkinson disease. Arch Neurol. 1999; 56:33-39.

88. Dickson, DW, Braak, H, Duda, JE, et al. Neuropathological assessment of Parkinson's disease: refining the diagnostic criteria. Lancet Neurol. 2009; 8:1150-1157.

89. Dickson, DW. Required techniques and useful molecular markers in the neuropathologic diagnosis of neurodegenerative diseases. Acta Neuropathol. 2005; 109:14-24.

90. Hyman, BT, Phelps, CH, Beach, TG, et al. National Institute on Aging-Alzheimer's Association guidelines for the neuropathologic assessment of Alzheimer's disease. Alzheimers Dement. 2012; 8:1-13.

91. Montine, TJ, Phelps, $\mathrm{CH}$, Beach, TG, et al. National Institute on Aging-Alzheimer's Association guidelines for the neuropathologic assessment of Alzheimer's disease: a practical approach. Acta Neuropathol. 2012; 123:1-11.

92. McKeith, IG, Dickson, DW, Lowe, J, et al. Diagnosis and management of dementia with Lewy bodies: third report of the DLB Consortium. Neurology. 2005; 65:1863-1872.

93. Serrano, GE, Walker, JE, Arce, R, et al. Mapping of SARS-CoV-2 Brain Invasion and Histopathology in COVID-19 Disease. medRxiv. 2021;2021.

94. Milbrandt, EB, Reade, MC, Lee, M, et al. Prevalence and significance of coagulation abnormalities in community-acquired pneumonia. Mol Med. 2009; 15:438-445.

95. Pilato, F, Profice, P, Dileone, M, et al. Stroke in critically ill patients. Minerva Anestesiol. 2009; $75: 245-250$. 
medRxiv preprint doi: https://doi.org/10.1101/2021.03.22.21254139; this version posted March 26, 2021. The copyright holder for this preprint (which was not certified by peer review) is the author/funder, who has granted medRxiv a license to display the preprint in perpetuity. It is made available under a CC-BY-NC-ND 4.0 International license .

96. Debette, S, Beiser, A, DeCarli, C, et al. Association of MRI markers of vascular brain injury with incident stroke, mild cognitive impairment, dementia, and mortality: the Framingham Offspring Study. Stroke. 2010; 41:600-606.

97. Pilato, E, Manzo, R, and Comentale, G. COVID-19 and ischemic heart disease emergencies: What cardiac surgery should expect? J Card Surg. 2020; 35:1161.

98. Oladiran, O and Nwosu, I. Stroke risk stratification in atrial fibrillation: a review of common risk factors. J Community Hosp Intern Med Perspect. 2019; 9:113-120.

99. Aronow, WS and Banach, M. Atrial Fibrillation: The New Epidemic of the Ageing World. J Atr Fibrillation. 2009; 1:154.

100. Roman, GC. Stroke, cognitive decline and vascular dementia: the silent epidemic of the 21 st century. Neuroepidemiology. 2003; 22:161-164.

101. Turner, GD, Bunthi, C, Wonodi, CB, et al. The role of postmortem studies in pneumonia etiology research. Clin Infect Dis. 2012; 54 Suppl 2:S165-S171.

102. Jain, S, Self, WH, Wunderink, RG, et al. Community-Acquired Pneumonia Requiring Hospitalization among U.S. Adults. N Engl J Med. 2015; 373:415-427.

103. Morens, DM, Taubenberger, JK, and Fauci, AS. Predominant role of bacterial pneumonia as a cause of death in pandemic influenza: implications for pandemic influenza preparedness. J Infect Dis. 2008; 198:962-970. 